\title{
Job Stress and Pyschological Well-Being among Library Employees: A Survey of Library Staff in Selected University Libraries in South-West Nigeria
}

\author{
Chinyere N. Ikonne \\ Department of Information Resources Management, Babcock University, Ilishan-Remo, Nigeria \\ Email: cikonne@yahoo.com
}

Received 1 June 2015; accepted 17 June 2015; published 26 June 2015

Copyright (C) 2015 by author and OALib.

This work is licensed under the Creative Commons Attribution International License (CC BY). http://creativecommons.org/licenses/by/4.0/

(c) $\underset{\mathrm{EY}}{\mathrm{B}}$ Open Access

\begin{abstract}
The study investigated job stress and the psychological well-being of library employees. It closely looked into role predictors of job stress namely, role ambiguity and role conflict as well as physical work environment issues; to determine their relationships on the psychological well-being of library staff in selected University libraries in South-West Nigeria. Survey research design was used for the study. The population consisted of 125 library staff. Sampling was total enumeration so as to accommodate all the library staff. Structured questionnaire was employed for data collection. Data collected were analyzed using frequency, percentage counts and mean. The general findings on job stress revealed that respondents had challenges with technology and excess or quantity of workload. Job stress resulting from role ambiguity was that the respondents were not certain of how much authority they have. As regards role conflict, majority of the respondents stated that it did not cause them any job stress. They also perceived their work environment as stress free. Findings from the hypotheses revealed that role ambiguity, role conflict, and work environment have a positive significant relationship on psychological well-being of the respondents. Based on these findings, this study made some recommendations.
\end{abstract}

\section{Keywords}

Stress, Job Stress, Psychological Well-Being, University Library Staff, Libraries, South-West Nigeria Subject Areas: Psychology, Sociology

\section{Introduction}

Many research studies have been conducted on job stress. Occupational stress, work stress or job stress are ter-

How to cite this paper: Ikonne, C.N. (2015) Job Stress and Pyschological Well-Being among Library Employees: A Survey of Library Staff in Selected University Libraries in South-West Nigeria. Open Access Library Journal, 2: e1632.

http://dx.doi.org/10.4236/oalib.1101632 
minologies that are used interchangeably which refer to the same thing [1]. Job stress has been perceived to be an important concept in the study of employees' responses to their work environments. Occupational stress can cause unusual and dysfunctional behavior at work and contributes to poor physical and mental health, thereby putting employees' health and organizational success at risk. Job stress is, therefore, considered a major issue in the occupational safety and health aspect as well as organizational well-being [2]. The salience of job stress as a research topic has resulted partly to the magnitude of its effects on employees. Work related stress has been related to organizational problems such as absenteeism, high turnover, poor job performance, accidents and errors, alcohol and drug abuse, burnout, and hypertension [3]-[5]. Its effect could also make employees who are physically present at work to perform and produce less [6]. Therefore, there is the perception that stressful employees are more likely to be unhealthy, poorly and less motivated, less safe at work, and consequently, affecting the psychological and emotional well-beings of the employees.

Concerns for the psychological health of human beings have led to the interest of researching into the psychological well-being of employees [7]. Well-being is one of the important goals that all human beings desire to achieve. [8] sees well-being as a term that defies a single definition. Some see well-being in the light of good health, welfare, comfort, security, and safety. Quality of life has also been used to describe well-being. [9] is of the opinion that quality of life is a multidimensional construct which comprises the physical, emotional, mental, social, and behavioral components. [10] adds that well-being is such a complex construct that in spite of all the attempts by researchers to have a clear meaning of it, they have not been able to find accurate ways to give a detailed explanation. Psychological well-being, according to [11], has been used in the literature synonymously and interchangeably with terms such as happiness, satisfaction with life experience and one's role in the world of work. Hope, positive affect, positive mental health, well being and quality of life, sense of achievement, utility, belongingness and no distress, dissatisfaction or worry have also been perceived as psychological well-being. It emphasizes on positive characteristics in terms of growth and development. In the view point of [12], psychological well-being has to do with people's feeling in the day-to-day life, and these feelings may vary from positive feelings, like satisfaction, to negative feelings, such as depression and dissatisfaction.

Library workers, no matter their classes, status or years of work experience, are not left out from experiencing stress while performing their functions. These stresses could emanate from pressures from various sources and these stresses may lead to health compromises and, consequently, affect the psychological well-being of the staff. Therefore, knowledge about job stress and the extent to which it influences the psychological well-being of the library staff could play a vital role in the management of staff and in improving those stressors that impact people. The result of this study may help the mangers in the management of these sources of job stress thereby improving the health concerns, performance, mental and psychological well-being of their staff.

\section{Objective of the Study}

The aim of this study is to investigate the relationship between job stress with particular emphasis on the role predictors of job stress namely role ambiguity and role conflict as well as physical work environmental factors, and to reveal their relationships on the psychological well-being of library staff in certain South-West Nigerian University libraries. The specific objectives are to:

1) discover the sources of job stress for the library staff in the university libraries in some South-West Nigeria.

2) find out if role ambiguity factors are sources of job stress among library staff in the university libraries in South-West Nigeria.

3) know if role conflict factors are sources of job stress among library staff in the university libraries in SouthWest Nigeria.

4) ascertain if physical work environment factors are sources of job stress among library staff in the university libraries in South-West Nigeria.

\section{Hypotheses for the Study}

In order to attain the above mentioned objectives, the following hypotheses were developed and tested at 0.05 level of significance.

1) There is no significant relationship between role ambiguity and psychological well-being of library staff.

2) There is no significant relationship between role conflict and psychological well-being of library staff. 
3) There is no significant relationship between physical work environment and psychological well-being of library staff.

\section{Review of Literature}

Job stress has been described as the harmful physical and emotional response that occurs when the job requirements do not match the capabilities, resources, or needs of the worker [13]. It is also considered as that response people may have when presented with work demands and pressures that are not matched to their knowledge and abilities which challenge their ability to cope. A report on a survey on upcoming generation of employees, according to [14], reveals that most of the employees desire greater meaning and personal development from their work. They see their work as a calling — enjoyable, fulfilling, and socially useful. This perception reveals that anything that might hinder them from achieving their works' calling will affect them and might lead to stressful condition for them which might compromise their well-being. Evidence from researchers like [15] has disclosed that well-being is very important to employers in relation to the individual-level of job satisfaction to individuallevel of performance.

There are several causes of job stress. Gallaper, 2002 (in [16]) posits that job stress is a growing concern for organizations today which libraries and library staff are not exceptions. [17] has identified six sources, namely, role overload, role insufficiency, role ambiguity, role boundary, role responsibility and physical environment. For library workers, [18] has identified work overload of a quantitative or qualitative nature; work underload, interpersonal relationships, lack of respect and recognition, interpersonal relationships, lack of effective positive feedback from supervisors, co-workers and patrons, expectations from others felt by library staff members (role ambiguity and role conflict), inadequate office space, career stage or career concerns, and technology and equipment as sources of job stress in the library workplace. In his workshops on stress, the library support staff reported that workload, inadequate training, knowledge, and frustrations on the job are the major causes of job stresses. The results of [19] study on the causes of stress among polytechnic librarians in Delta State of Nigeria reveals that pressure from management/bosses, poor work environment, excess workload, inadequate support system, challenges in coping with new technology and lack of supervision are major sources of job stress.

As has been observed by [20], the library staff, in particular, academic librarians, in an attempt to tackle the emerging challenges in their profession during this information age, are bound to face new expectation from their employers and patrons. Further, the roles of the library staff are constantly changing due to the dynamic nature of information, its delivery, the emergence of ICT in the library, and funding problems. All these have culminated in the growth of stress among staff. A by-product of working in a technological environment is techno-stress which according to [21], has to do with the problem of adaptation to a new technology. In his online survey on techno-stress (computer-related stress) among library staff who work in academic libraries, [22] discovered that fifty-nine (59\%) percent of survey participants said their level of computer-related stress has increased in the past 5 years, thirty-four percent (34\%) felt it has not changed much, and only $4 \%$ believed it has decreased. Out of the major causes of techno-stress were computer hardware (technology) and ergonomics, networking problems, information overload, security issues, and vendor-produced databases as well as lack of training. The study of [23] on library staff on stress reveals that job difficulty, insufficient or too little training with technology, the rate at which things change is too fast and complicated, and unrealistic pressure to produce are sources of job stress.

Factors such as the state of work environment, personal or internal factors, home-work interface, professional and or academic demand, job security, job satisfaction and management problems equally introduce job stress among staff (Skillsoft, 2006 in [16]). Further, [24] indentified managerial motivated stress; self engineered stress, job insecurity stress, financially motivated stress, technological as well as task/duty fueled stress, and management style adopted by the managers/administrators as other sources of job stress. These, [25] maintains, lead to increased sick leave, absenteeism, premature labor turn-over and retirement due to ill health, loss of quality production and value and employee litigation against the institution. It is argued that the cost of stress related illness and absenteeism to the library could be huge. Ferkol, 1998 (in [16]) therefore, concludes that the level of stress experienced by information workers increases geometrically while management understating of stress increases arithmetically. Ferkol therefore, cautions that if urgent steps are not taken, efficient services of the libraries will be jeopardized. So, job stress issues among personnel should be addressed to avert the inseparable damage that it might pose on the services and functions of the libraries in general, as well as affecting the psy- 
chological well-being of the personnel.

As has been explained by [26], job stress has a major concern in the occupational safety, health aspects as well as in organizational well-being. Some studies have been conducted using many variables to determine the influence of job stress on psychological well-being of employees. In examining the relationship between psychological well-being and job insecurity among 600 employees in the UK, [27] found a lower level of psychological well-being among those who felt insecure about their jobs. [11] studied the psychological well-being among public and private bank employees in India and their study revealed that the psychological well-being of employees is higher in public sector as compared to those in the private sector banks. In her survey of stress and wellbeing in Australia, [28] found out that Australians had significantly lower levels of wellbeing and significantly higher levels of stress and distress, depressive and anxiety symptoms than in the previous year. The study of [29] on the occupational stress, psychological well-being and workers' behavior in manufacturing industries in South-West Nigeria revealed that that there is a significant influence of occupational stress on psychological well-being of the respondents. In the study of stress from role ambiguity and psychological well-being of government officers in Malaysia, [30] found that there is a significant correlation between role ambiguity and psychological well-being.

Individuals are always subjected to work conflicts which carry a lot of ambiguities as well as complexities. According to [31] role stressors consist of two related but distinct construct, notably role ambiguity and role conflict. [31] [32] state that role ambiguity is referred to as lack of clear expectation and specific information regarding work role methods and requirements. This ambiguity occurs when one is not having a clear feedback from others about one's responsibilities and performance ([33], and also arises when a person does not have a clear picture about his work objectives, the scope and responsibilities of his own job as well as his co-workers' expectation of him ([4]). Since a worker needs to understand clearly what one's roles are and consequently, when this information is not clearly known, role ambiguity arises. [34] report that this could lead to higher levels of job tension and also directly lead to lower levels of job satisfaction for temporary employees. [35] argues that under this circumstance, one becomes afraid to act or take responsibility for anything. In lacking the necessary information to perform a job or a task, [36] points out that this situation is likely to result on a feeling of helplessness and uncertain of what is expected on the one's role set. [37], therefore, claims that the problem of role ambiguity could be attributed to inadequate training, poor communication, or the purposefully withholding or distortion of information by others. For the library and information professionals, [38] explains that stress resulting from role ambiguity comes about when an employee does not know that for which he or she is responsible. In addition, when employees do not use their skills, it can be as stressful as being overworked. Librarians may experience stress in assisting patrons because they do not have time to become an expert on each and every system.

A general problem that arises in understanding role behavior is that individuals play multiple roles, adjusting their roles to the group to which they belong at the time. A situation of role conflict exists when two or more employees have different views regarding their work and when individuals are required to play two or more roles that work against each other. Role conflicts create expectations that may be difficult to reconcile; and they create conflicting demands and expectations which lead employees in making incompatible decisions, [31]. Therefore, role conflict could be defined as a condition that occurs when an individual is subjected to competing or conflicting sets of expectations and demands in the organization, or when the principle of chain of command or the principle of unity of command is violated, [31]. For [39] role conflict is the extent to which a person experiences pressures within one role that are incompatible with pressures that arise within another role. In his argument, [35] maintains that the one may be caught between in the crossfire between two supervisors or the needs of two functional groups. Based on this, [36] declares that role conflict is a feeling of being torn in multiple directions, as one is unable to find a way to make every role partner satisfied. Therefore, when an individual is confronted by different role expectations, the person is experiencing role conflict [40].

Facets of role conflict, as has been pointed out by [41] include being torn by conflicting demands from a supervisor about the job and being pressured to get along with people with whom you are not compatible. As regards the influence of role conflict on library and information professionals, [38] discovers that due to the fact that library and information professionals have various supervisors who do not agree on what the employee should be doing results in job conflict which eventually leads to job stress. Some studies have been done in relation to the relationships that exists between role conflict and psychological well-being. Fairbrother, Cai and Zhang (in [30]) and [42] discovered in their studies that there is positive relationship between role conflict and 
psychological well being. In a study conducted by [30], it was discovered that occupational stress has a significant positive correlation with psychological well-being.

Job stress has long been an important concept in the study of employees' responses to their physical work environments. [43] asserts that there are many challenges in the work environment such as increased work targets, threats of job loss, organizational change, lack of time, lack of space, continuous technological development, and conflicting demand from organizational stakeholders which lead to stressful condition. Among these challenges is also the issue of the physical condition of work environment demands caused by temperature extremes, poorly designed offices; poor lighting, poorly heated or cooled offices, and excessive noise, [44]; all of which are perceived as poor ergonomic factors. These situations result in stress as the worker can no longer handle the effect of these conditions. Eventually, they lead to the hindering or slowing down of the employee's performance; leading to frustration and eventually and causing threats to employees' health. For instance, [45] notes that poor work processes, poor environment, improper workplace design and unsuitable working conditions are factors that could cause or aggravate conditions referred to as Carpel Tunnel Syndrome, Tenosynovitis, Repetitive Strain Injury (RSI) or Repetitive Motion Injury. In addition, excessive noise in the work environment has been perceived to have been linked to physiological problems such as hypertension, heart irregularities, digestive disorders, extreme fatigue, ulcers, allergies, fears, and neurological disorders [46].

Further, poor indoor air quality in one's work environment, according to [47], is likely to affect individuals' well-being. Adequate ventilation is necessary to remove indoor-generated pollutants from indoor air as they can have negative impact on several important human outcomes such as communicable respiratory illnesses, sick building syndrome symptom, task performance and productivity, perceived air quality and respiratory allergies as well as asthma [48]. So, if poor indoor air quality in the work environment is left unchecked, this condition could lead to workers taking a long break, increase in complaints and sick leave, mistakes and risks of accidents at work. All these would negatively influence the psychological well-being of the individuals involved.

[49] in his search found that the ability to personalize one's work area was positively related to environmental satisfaction which, in turn, positively influenced job satisfaction and employee well-being. Wells, using structural equation modeling, found that higher satisfaction with the physical environment predicted higher job satisfaction which, in turn, predicted higher employee well-being. Similarly, [50] demonstrated positive links between satisfaction with physical working conditions, job satisfaction and employee physical and mental wellbeing. There is also evidence that better physical health is correlated with higher job satisfaction and other factors such as lower job stress and better psychological well-being [51]. A workplace that is psychologically healthy will foster employee's health and well-being while enhancing organizational performance and productivity. Therefore, the ability of workplace to promote well-being rather than engender strains and mental illness is of considerable benefit to both employees and employers.

\section{Research Methodology}

The study employed descriptive survey research design to collect data in order to answer questions concerning the current status of the subject of the study. This design was chosen because the study is a self-report research that would enable the researcher to collect data from the library staff in the four (4) selected University libraries in South-West Nigeria, so as to determine the relationships between the predictors of job stress namely role ambiguity, role conflict and work environment on the psychological well-being of library staff. The population was made of 125 library employees in the selected University libraries in South-West Nigeria. Sampling was enumerative so as to ensure that all members of the population were used for the study. Variable such as gender, age and position in the library were determined from the responses of the respondents from the questionnaire. The questionnaire was the only instrument used in the collection of the data for this study. The researcher adopted [31] research questions for role ambiguity and role conflict. Data was analyzed using descriptive statistics of percentages, frequency count and mean.

\section{Presentation of Findings}

A total of 137 copies of questionnaires were distributed and 125 copies (91.2\%) were returned.

Table 1 reveals the demographic information of the respondents. It is shown that 68 (54.4\%) of the respondents are male, while 57 (45.6\%) are female. Hence, most of the respondents are male. From the table, it is also revealed that $63(50.4 \%)$ of the respondents are within the ages of 20 - 30 years, 29 (23.2\%) are within the ages 
of 31 - 45 years, while 33 (26.4\%) are within the ages 45 years and above. So, most of the respondents are within the ages of $20-30$ years. In relation to the position in the library, it is revealed that $60(48 \%)$ are professional librarians, 18 (14.4\%) are para-professionals, 42 (33.6\%) are library assistants, while 5 (4\%) are administrative staff.

Table 2 reveals the respondents by questionnaire distribution. From the table 31 (83.8\%) of the respondents are from Babcock University, 45 (90\%) are from University of Lagos (main Library), 39 (97.5\%) are from University of Ibadan (Kenneth Dike library) and $10(100 \%)$ are from Lead City University. Hence, most of the respondents are from University of Lagos (main library).

Table 3 reveals the respondents' view on specific sources of job stress in the library. It is revealed from the responses that the major causes of job stress are challenges with computer related problems/technology (56\%), nature of work (52\%), heavy job demands (48\%), management problems (47.2\%), tight academic and professional demands (47.2\%), and too heavy or excess work load (42.4\%). On the other hand, job insecurity and low salary with $28.8 \%$ and $28 \%$ respectively were seen to be the least job stressors.

Table 4 shows the respondents' view on role ambiguity sources of job stress. From the table it is shown that $61.6 \%$ of the respondents do not feel certain about how much authority they have. Apart from this, 95\% of the respondents know exactly what is expected of them, $90 \%$ of them know what their responsibilities are, $86 \%$ of them have divided their time properly, $80 \%$ of them receive clear explanations of what has to be done $80 \%$ and $76 \%$ of the respondents responded that they have cleared, planned objectives for their jobs.

As regards respondents' opinion on role conflict as a source of job stress, some of the notable responses are the disagreement that they do things that are appropriate to be accepted by one person and not accepted by

Table 1. Demographic details of respondents.

\begin{tabular}{|c|c|c|c|c|c|c|}
\hline & & & Frequency & $\%$ & Valid \% & Cumulative \% \\
\hline \multirow{4}{*}{ Gender } & \multirow{4}{*}{ Valid } & Male & 62 & 49.6 & 49.6 & 49.6 \\
\hline & & Female & 57 & 45.6 & 45.6 & 95.2 \\
\hline & & 3.00 & 6 & 4.8 & 4.8 & 100.0 \\
\hline & & Total & 125 & 100.0 & 100.0 & \\
\hline \multirow{4}{*}{ Age (in years) } & \multirow{4}{*}{ Valid } & $20-30$ & 63 & 50.4 & 50.4 & 50.4 \\
\hline & & $31-45$ & 29 & 23.2 & 23.2 & 73.6 \\
\hline & & 45 and above & 33 & 26.4 & 26.4 & 100.0 \\
\hline & & Total & 125 & 100.0 & 100.0 & \\
\hline \multirow{5}{*}{$\begin{array}{l}\text { Position in the } \\
\text { Library }\end{array}$} & \multirow{5}{*}{ Valid } & Professional librarian & 60 & 48.0 & 48.0 & 48.0 \\
\hline & & Para-professional librarian & 18 & 14.4 & 14.4 & 62.4 \\
\hline & & Library assistant & 42 & 33.6 & 33.6 & 96.0 \\
\hline & & Administrative staff & 5 & 4.0 & 4.0 & 100.0 \\
\hline & & Total & 125 & 100.0 & 100.0 & \\
\hline
\end{tabular}

Table 2. Questionnaire distribution by university library.

\begin{tabular}{|c|c|c|c|c|c|}
\hline $\mathrm{S} / \mathrm{N}$ & Name of university library & $\begin{array}{l}\text { No. of questionnaires } \\
\text { administered }\end{array}$ & $\begin{array}{c}\text { No. of questionnaires } \\
\text { returned }\end{array}$ & $\begin{array}{l}\text { Copies not } \\
\text { returned }\end{array}$ & $\begin{array}{c}\text { Percentage } \\
\text { returned }\end{array}$ \\
\hline 1 & Babcock University Library & 37 & 31 & 6 & 83.8 \\
\hline 2 & University of Lagos (Main Library) & 50 & 45 & 5 & 90.0 \\
\hline 3 & University of Ibadan (Kenneth Dike) Library & 40 & 39 & 1 & 97.5 \\
\hline \multirow[t]{2}{*}{4} & Lead City University Library & 10 & 10 & 0 & 100 \\
\hline & Total & 137 & 125 & 12 & 100 \\
\hline
\end{tabular}


Table 3. Job stress.

\begin{tabular}{ccccc}
\hline S/N & Statement & Agree & Not agree & Neutral \\
\hline 1 & Challenges with computer related problems/technology & $70(56 \%)$ & $49(39.2 \%)$ & $6(4.8)$ \\
2 & Nature of work & $65(52 \%)$ & $48(38.4 \%)$ & $12(9.6 \%)$ \\
3 & Heavy job demands & $60(48 \%)$ & $65(52 \%)$ & 0 \\
4 & Management problems & $59(47.2 \%)$ & $60(48 \%)$ & $6(4.8 \%)$ \\
5 & Tight academic and professional demands & $59(47.2 \%)$ & $54(43.2 \%)$ & $12(9.6 \%)$ \\
6 & Too heavy or excess workload & $53(42.4 \%)$ & $54(43.2 \%)$ & $18(14.4 \%)$ \\
7 & Much work pressure & $48(38.4 \%)$ & $71(56.8 \%)$ & $6(4.8 \%)$ \\
8 & Inadequate support system & $48(38.4 \%)$ & $77(61.6 \%)$ & 0 \\
10 & Job insecurity & $36(28.8 \%)$ & $77(61.6 \%)$ & $12(9.6 \%)$ \\
\hline
\end{tabular}

Table 4. Role ambiguity and role conflict.

\begin{tabular}{|c|c|c|c|c|}
\hline $\mathbf{S} / \mathbf{N}$ & Role ambiguity statement & Agree & Not agree & Neutral \\
\hline 1 & I feel certain about how much authority I have & $18(14.4 \%)$ & $77(61.6 \%)$ & $30(24 \%)$ \\
\hline 2 & I have clear, planned objectives for my job & $95(76 \%)$ & $6(4.8 \%)$ & $24(19.2 \%)$ \\
\hline 3 & I know that I have divided my time properly & $108(86.4 \%)$ & $11(8.8 \%)$ & $6(4.8 \%)$ \\
\hline 4 & I know what my responsibilities are & $113(90.4 \%)$ & $12(9.6 \%)$ & 0 \\
\hline 5 & I know exactly what is expected of me & 119 (95.2\%) & $6(4.8 \%)$ & 0 \\
\hline 6 & I receive clear explanations of what has to be done & $101(80.8 \%)$ & $6(4.6 \%)$ & $18(14.4 \%)$ \\
\hline 7 & I feel certain how I will be evaluated for a raise or promotion & $85(68 \%)$ & $16(12.8 \%)$ & $24(19.2 \%)$ \\
\hline 8 & I am able to act the same regardless of the group I am with & $66(52.8 \%)$ & $29(23.2 \%)$ & $30(24 \%)$ \\
\hline $\mathbf{S} / \mathbf{N}$ & Role conflict statement & Agree & Not agree & Neutral \\
\hline 1 & I have to do things that should be done differently & $40(32 \%)$ & $56(44.8 \%)$ & $29(23.2 \%)$ \\
\hline 2 & I have an assignment without the manpower to complete it & $42(33.6 \%)$ & $71(56.8 \%)$ & $42(33.6 \%)$ \\
\hline 3 & I have to work with two or more groups who operate quite differently & $23(18.4 \%)$ & $54(43.2 \%)$ & $48(38.4 \%)$ \\
\hline 4 & I receive incompatible requests from two or more people & $17(13.6 \%)$ & $54(43.2 \%)$ & $54(43.2 \%)$ \\
\hline 5 & $\begin{array}{l}\text { I do things that are appropriate to be accepted by one } \\
\text { person and not accepted by others }\end{array}$ & $18(14.4 \%)$ & $107(85.6 \%)$ & 0 \\
\hline 6 & I receive assignment without adequate resources and materials to execute it & $11(8.8 \%)$ & $84(67.2 \%)$ & $30(24 \%)$ \\
\hline 7 & My job has a lot of responsibility, but I don't have very much authority & $46(36.8 \%)$ & $49(39.2 \%)$ & $30(24 \%)$ \\
\hline 8 & I have to work under vague directives or orders & $22(17.6 \%)$ & $55(44 \%)$ & $48(38.4 \%)$ \\
\hline
\end{tabular}

others (85.6\%); that they receive assignment without adequate resources and materials to execute it (67.2\%) and have received assignment without the manpower to complete it (56.8\%). About $43.2 \%$ of them are neutral as regards receiving incompatible requests from two or more people.

Table 5 indicates the respondents' opinion on work environment. From the result it is revealed that most of the respondents did not see poorly designed workplace, office and equipment problems, poor lighting, much noise and distraction in their office as sources of stress. They perceived their workplace environment as pleasant or safe place as indicated in the "not agree" responses on the table. 
Table 5. Work environment.

\begin{tabular}{|c|c|c|c|c|}
\hline $\mathbf{S} / \mathbf{N}$ & Statement & Agree & Not agree & Neutral \\
\hline 1 & Poorly designed workplace & $21(16.8 \%)$ & $92(73.6 \%)$ & $12(9.6 \%)$ \\
\hline 2 & Office and equipment problems & $17(13.6 \%)$ & $96(76.8 \%)$ & $12(9.6 \%)$ \\
\hline 3 & Poor lighting & $12(9.6 \%)$ & $107(85.6 \%)$ & $6(4.8 \%)$ \\
\hline 4 & Much noise and distraction in my office & $12(9.6 \%)$ & $107(85.6 \%)$ & $6(4.8 \%)$ \\
\hline 5 & Workplace environment is not pleasant or safe & $11(8.8 \%)$ & $102(81.6 \%)$ & $12(9.6 \%)$ \\
\hline 6 & Inadequate fresh air in the office? & $6(4.8 \%)$ & $107(85.6 \%)$ & $12(9.6 \%)$ \\
\hline 7 & Unpleasant or dangerous physical conditions & $6(4.8 \%)$ & 107 (85.6\%) & $12(9.6 \%)$ \\
\hline 8 & Poor office ventilation & 0 & $119(95.2 \%)$ & $6(4.8 \%)$ \\
\hline 9 & Uncomfortable workspace/workplace & 0 & $101(80.8 \%)$ & $24(19.2 \%)$ \\
\hline 10 & Poorly heated or cooled offices & 0 & $107(85.6 \%)$ & $18(14.4 \%)$ \\
\hline
\end{tabular}

\section{Testing of Hypotheses and Presentation of Results}

This segment presents the results of the formulated null hypotheses tested at 0.05 significance level.

Hypothesis One: There is no significant relationship between role ambiguity and psychological well-being of library staff.

The result from Table 6 shows a strong positive relationship between role ambiguity and psychological well-being. This was tested using correlation which value is 0.822 and is significant at $\mathrm{p}<0.05$ with mean value of 4.5322 and standard deviation of 2.3441 for the first variable while the second variable has mean value of 4.4214 and standard deviation of 0.2893 . This, therefore, implies that there is a significant relationship between role ambiguity and psychological well-being.

Hypothesis Two: There is no significant relationship between role conflict and psychological well-being of library staff.

The result from Table 7 reveals a strong positive relationship between role conflict and psychological wellbeing. This was tested using correlation which value is 0.612 and is significant at $\mathrm{p}<0.05$ with mean value of 3.3172 and standard deviation of 0.3921 for the first variable while the second variable has mean value of 4.4214 and standard deviation of 0.2893 . This, therefore, indicates that there is a significant relationship between role conflict and psychological well-being.

Hypothesis Three: There is no significant relationship between work environment and psychological wellbeing of library staff.

The result as shown in Table 8 reveals a strong positive relationship between work environment and psychological well-being. This was tested using correlation which value is 0.764 and is significant at $\mathrm{p}<0.05$ with mean value of 3.3561 and standard deviation of 0.4021 for the first variable while the second variable has mean value of 4.5213 and standard deviation of 0.3634 . Therefore, this implies that there is a significant relationship between work environment and psychological well-being.

\section{Discussion of Findings}

This study focused on the relationship between some factors that cause job stress. It specifically indentified role ambiguity, role conflict, and work environment as sources of job stress. It also investigated the relationship that exists between role ambiguity, role conflict, work environment and psychological well-being of library staff in South-West Nigeria University libraries. In considering some of the major factors that resulted in job stress for the respondents, Table 3 revealed that challenges with technology and excess or quantity of workload are major causes of job stress for the respondents. These findings corroborated those of [22] and [19] who discovered from their studies that problems and challenges with of technology is a source of stress to library workers. [18], [19], and [4] also reported from their studies that excess workload or quantity of work load is major source of job stress for library staff an in all types of occupations. 
Table 6. Relationship between role ambiguity and psychological well-being.

\begin{tabular}{cccccc}
\hline Variables & Correlation (r) & Mean & Std. D & Prob. & Remark \\
\hline Role ambiguity & 0.822 & 4.5322 & 2.3441 & & Significant \\
Psychological well-being & & 4.4214 & 0.2893 & & \\
N & & & & & \\
\end{tabular}

Table 7. Relationship between role conflict and psychological well-being.

\begin{tabular}{cccccc}
\hline Variables & Correlation (r) & Mean & Std. D & Prob. & Remark \\
\hline Role conflict & & 3.3172 & 0.3921 & & Significant \\
Psychological well-being & 0.612 & 4.4214 & 0.2893 & & \\
N & & & & & \\
\hline
\end{tabular}

Table 8. Relationship between work environment and psychological well-being.

\begin{tabular}{ccccc}
\hline Variables & Correlation (r) & Mean & Std. D & Prob. \\
\hline Work environment & & 3.3561 & 0.4021 & 0.031 \\
Psychological well-being & $\mathbf{0 . 7 6 4}$ & 4.5213 & 0.3634 & Significant \\
$\mathbf{N}$ & & & &
\end{tabular}

When factors of role ambiguity as is shown in Table 4 were considered, it was found that the only source of job stress for respondents was that they do not feel certain about how much authority they have (61.6\%). Apart from this, role ambiguity is not seriously perceived as major source of job stress for the respondents. In connection with role conflict as is also indicated in Table 5, the respondents did not agree that role conflict is a source of stress. However, quite a number of them are neutral on issues like I receive incompatible requests from two or more people (43.2\%); I have to work with two or more groups who operate quite differently (38.4\%) and I have to work under vague directives or orders (38.4\%). Finally, the result of this study reveals that physical work environment as is seen in Table 5 is not a source of job stress for the respondents of this study.

The hypotheses tested, revealed the following: The first hypothesis which predicted that there is no significant relationship between role ambiguity stress and psychological well-being is shown to have a significant relationship as is shown in Table 6. [30] study reported that four dimensions of occupational stress, namely role overload, role insufficiency, role ambiguity and role boundary have significant relationships and influence on psychological well-being.

The second hypothesis stated that there is no significant relationship between role conflict and psychological well-being of respondents. The finding as revealed in Table 7 shows that role conflict has a positive effect on the psychological well-being, and this implies that this hypothesis is confirmed. This finding corroborated with the findings of Fairbrother, Cai and Zhang, 2008 (in [30]), [42] and [30], who discovered in their studies that there is positive relationship between role conflict and psychological well being.

The last hypothesis said that there is no significant relationship between physical work environment and psychological well-being of the respondents revealed that physical work environment has a positive relationship on the psychological well-being of library staff as is indicated in Table 8 . This infers that this statement can be accepted. This finding is supported by the findings of [49] and [51] who found in their works that there is a positive link between satisfaction with physical working conditions, job satisfaction, and employee physical and mental well-being.

\section{Conclusion and Recommendation}

Based on the findings, the study concludes that the library staffs in selected University libraries in South-West Nigeria have generally identified some problems resulting from job stress. In addition, the study has revealed 
that there exists a positive relationship between role ambiguity and role conflict and also physical work environment and psychological well-being. On these established facts, the study recommends that the library administration makes effort in creating awareness of and understanding those factors that result in job stress for the library staff. More, the organization should strive to implement measures of intervention to curb these stressors. Further, since role ambiguity is attributed to lack of clear or effective communication, improvement in communication between the staff and their bosses/supervisors is encouraged. Finally, it is also recommended that measures that would cater for the welfare and psychological well-being of the library staff be clearly stated in the strategic plan of the administration. This will help over-see the needs and challenges of the library staff. A part of it will be to create a suitable work environment and this could help alleviate the magnitude effects of stress-related problems on the well-being of library staff.

\section{References}

[1] Larson, L.L. (2004) Internal Auditors and Job Stress. Managerial Auditing Journal, 19, 1119-1130. http://dx.doi.org/10.1108/02686900410562768

[2] Noblet, A., Rodwell, J. and McWilliams, J. (2002) The Job Strain Model Is Enough for Managers. Journal of Managerial Psychology, 16, 635-649. http://dx.doi.org/10.1108/EUM0000000006304

[3] Mimura, C. and Griffiths, P. (2003) The Effectiveness of Current Approaches to Workplace Stress Management in the Nursing Profession: An Evidence Based Literature Review. Occupational and Environmental Medicine, 60, 10-15. http://dx.doi.org/10.1136/oem.60.1.10

[4] Manshor, A.T., Fontaine, R. and Chong, S.C. (2003) Occupational Stress among Managers: A Malaysian Survey. Journal of Managerial Psychology, 18, 622-628. http://dx.doi.org/10.1108/02683940310494412

[5] O’Connor, D.B., O’Connor, R.C., White, B.L. and Bundred, P.E. (2000) Job Strain and Ambulatory Blood Pressure in British General Practitioners: A Preliminary Study. Psychology, Health and Medicine, 5, 241-250. http://dx.doi.org/10.1080/713690191

[6] Caverley, N. (2005) Civil Service Resiliency and Coping. International Journal of Public Sector Management, 18, 401-413. http://dx.doi.org/10.1108/09513550510608868

[7] Samuel, M.O., Osinowo, H.O. and Chipunza, C. (2009) The Relationship between Bank Distress, Job Satisfaction, Perceived Stress and Psychological Well-Being of Employees and Depositors in Nigeria's Banking Sector. African Journal of Business Management, 3, 624-632.

[8] Amichai-Hamburger, Y. (2008) Technology and Psychological Wellbeing. Cambridge University Press, Cambridge.

[9] Janse, A.J., Gemke, R.J., Uiterwaal, C.S., Van Der Tweel, I., Kimpen, J.L. and Sinnema, G. (2004) Quality of Life: Patients and Doctors Don’t Always Agree: A Meta-Analysis. Journal of Clinical Epidemiology, 57, 653-661. http://dx.doi.org/10.1016/j.jclinepi.2003.11.013

[10] Pollard, E. and Lee, P.D. (2003) Child Well-Being: A Systematic Review of the Literature. Social Indicators Research, 61, 59-78. http://dx.doi.org/10.1023/A:1021284215801

[11] Warr, P. (1978) A Study of Psychological Well-Being. British Journal of Psychology, 69, 111-112. http://dx.doi.org/10.1111/j.2044-8295.1978.tb01638.x

[12] Alam, S. and Rizvi, K. (2012) Psychological Well-Being among Bank Employees. Journal of the Indian Academy of Applied Psychology, 38, 242-247.

[13] Marzabadi, E.A. and Tarkhorani, N. (2007) Job Stress, Job Satisfaction and Mental Health. Journal of Clinical and Diagnostic Research, 4, 224-234.

[14] Avolio, B.J. and Sosik, J.J. (1999) A Lifespan Framework for Assessing of Work on White Collar. In: S.L. Willis and J.D. Reid, Eds., Life in the Middle: Psychological and Social Development Age, Academic Press, San Diego, 251-274. http://dx.doi.org/10.1016/B978-012757230-7/50032-8

[15] Judge, T.A., Thoresen, C.J., Bono, J.E. and Patton, G.K. (2001) The Job Satisfaction-Job Performance Relationship: A Qualitative and Quantitative Review. Psychological Bulletin, 127, 376-407. http://dx.doi.org/10.1037/0033-2909.127.3.376

[16] Osipow, S.H. (1988) Occupational Stress Inventory Manual (Professional Version). Psychological Assessment Resources, Odessa.

[17] Ozioko, R.E., Uwakwe, J.E. and Asadu, B.U. (2014) Job Stress among Staff in Polytechnic Libraries of North-Central, Nigeria. Paripex-Indian Journal of Research, 3, 89-92. http://theglobaljournals.com/paripex/file.php?val=March_2014_1394869580_a457c_30.pdf

[18] Bunge, C.A. (1989) Stress in the Library Workplace. Library Trends, 38, 92-102. 
https://www.ideals.illinois.edu/bitstream/handle/2142/7642/librarytrendsv38i1k_opt.pdf

[19] Babatope, I.S. (2013) Causes and Effects of Job Related Stress among Polytechnic Librarians in Delta State, Nigeria. International Journal of Library Science, 2, 1-5.

[20] Graig, M. (2008) Office Workers Survival Handbook. BSSR, Landon.

[21] Tarafdar, M., Tu, Q., Ragu-Nathan, B.S. and Ragu-Nathan, T.S. (2007) The Impact of Technostress on Role Stress and Productivity. Journal of Information Management Systems, 24, 301-328. http://dx.doi.org/10.2753/MIS0742-1222240109

[22] Kupersmith, J. (2003) Library Technostress Survey Results. http://www.jkup.net/tstress-survey-2003.html

[23] Jones, D.E. (1999) Ten Years Later: Support Staff Perceptions and Opinions on Technology in the Workplace. Library Trends, 47, 711-745.

[24] Dave, P. (2005) What Work Place Stress Research Is Telling Communication. Technical Communication, 52, 449-455.

[25] Hart, J. (2010) Stress and Job Satisfaction among Engineers on a Public Library System. Library and Information Science Research, 13, 25-59.

[26] Williams, J.S. and Cooper, C.L. (1998) Measuring Occupational Stress: Development of the Pressure Management Indicator. Journal of Occupational Health Psychology, 4, 306-321. http://dx.doi.org/10.1037/1076-8998.3.4.306

[27] Burchell, B. (1992) Towards a Social Psychology of the Labour Market: Or Why We Need to Understand the Labour Market before We Can Understand Employment. Journal of Occupational and Organizational Psychology, 65, 345354. http://dx.doi.org/10.1111/j.2044-8325.1992.tb00510.x

[28] Casey, L. (2013) Stress and Wellbeing in Australia Survey 2013. Australian Psychological Society. http://www.psychology.org.au/Assets/Files/Stress\%20and\%20wellbeing\%20in\%20Australia\%20survey\%202013.pdf

[29] Akintayo, D.I. (2012) Occupational Stress, Psychological Well Being and Workers’ Behaviour in Manufacturing Industries in South-West Nigeria. Research Journal in Organizational Psychology \& Educational Studies, 1, 289-294.

[30] Yunus, J.B.M. and Bin Mahajar, A.J. (2011) Stress and Psychological Well-Being of Government Officers in Malaysia. The Journal of Human Resource and Adult Learning, 7, 40-50. http://www.hraljournal.com/Page/5\%20Abdul\%20Jumaat\%20bin\%20Mahajar.pdf

[31] Rizzo, J.R., House, R.J. and Lirtzman, S.I. (1970) Role Conflict and Ambiguity in Complex Organizations. Administrative Science Quarterly, 15, 150-163. http://dx.doi.org/10.2307/2391486

[32] Quah, J. and Campbell, K.M. (1994) Role Conflict and Role Ambiguity as Factors in Work Stress among Managers in Singapore: Some Moderator Variables. Research and Practice in Human Resource Management, 2, 21-33.

[33] Ahmady, S., Changiz, T., Masiello, I. and Brommels, M. (2007) Organizational Role Stress among Medical School Faculty Members in Iran: Dealing with Role Conflict. BMC Medical Education, 7, 14. http://www.ncbi.nlm.nih.gov/pmc/articles/PMC1892550/ http://dx.doi.org/10.1186/1472-6920-7-14

[34] Slatterya, J.P., Selvarajanb, T. and Andersonc, J.E. (2008) The Influences of New Employee Development Practices upon Role Stressors and Work-Related Attitudes of Temporary Employee. The International Journal of Human Resource Management, 19, 2268-2293. http://dx.doi.org/10.1080/09585190802479512

[35] Jones, G.R. (2007) Organizational Theory, Design, and Change. 5th Edition, Pearson Education, Inc., Upper Saddle River.

[36] Onyemah, V. (2008) Role Ambiguity, Role Conflict, and Performance: Empirical Evidence of an Inverted-U Relationship. Journal of Personal Selling \& Sales Management, 28, 299-313. http://dx.doi.org/10.2753/PSS0885-3134280306

[37] Luthans, F. (1989) Organizational Behavior. 5th Edition, McGraw-Hill Inc., New York.

[38] Nawe, J. (1995) Work-Related Stress among the Library and Information Work Force. Library Review, 44, 30-37. http://dx.doi.org/10.1108/00242539510093674

[39] Kopelman, R.E., Greenhaus, J.H. and Connoly, T.F. (1983) A Model of Work, Family, and Interrole Conflict: A Construct Validation Study. Organizational Behavior and Human Performance, 32, 198-215. http://dx.doi.org/10.1016/0030-5073(83)90147-2

[40] Robbins, S.P. and Coulter, M. (2003) Management. 7th Edition, Prentice Hall, Upper Saddle River, 372.

[41] Ivanceivich, J.M., Konopaske, R. and Matteson, M.T. (2008) Organizational Behavior and Management. 8th Edition, McGraw-Hill Irwin, New York.

[42] Chandaraaiah, K., Agrawal, S.C., Marimuthu, P. and Manoharan, N. (2003) Occupational Stress and Job Satisfaction among Managers. Indian Journal of Occupational and Environmental Medicine, 7, 6-11.

[43] McHugh, M. (1997) The Stress Factor: Another Item for the Change Management Agenda? Journal of Organizational 
Change Management, 10, 345-362. http://dx.doi.org/10.1108/09534819710175866

[44] Griffin, R.W. (1996) Management: Boston Houghton Mifflin Company.

[45] Akhahowa, A.E. (2007) Occupational Overuse Syndrome (OOS): A Recurring Problem in the Computer Industry of Industrially Developing Countries (IDCs). A Case Study at University of Benin, Benin City, Nigeria. HFESA Journal, Ergonomics Australia, 21, 10-19.

[46] Engel, Z., Augustynska, D., Koton, J. and Kacmarska, A. (2006) Noise: definitions. In: Karwowski, W., Ed., International Encyclopedia of Ergonomics and Human Factors, CRC, Boca Raton. http://dx.doi.org/10.1201/9780849375477.ch361

[47] Mahbob, N.S., Kamaruzzamani, S.N., Salleh, N. and Sulaiman, R. (2011) A Correlation Studies of Indoor Environmental Quality (IEQ) towards Productive Workplace. 2nd International Conference on Environmental Science and Technology, IPCBEE, 6, 434-438.

[48] Seppänen, O.A. and Fisk, W.J. (2004) Summary of Human Responses to Ventilation. Indoor Air, 4, 102-118. http://dx.doi.org/10.1111/j.1600-0668.2004.00279.x

[49] Wells, M.M. (2000) Office Clutter or Meaningful Personal Displays: The Role of Office Personalization in Employee and Organizational Well-Being. Journal of Environmental Psychology, 20, 239-251. http://dx.doi.org/10.1006/jevp.1999.0166

[50] Donald, I. and Siu, O. (2001) Moderating the Stress Impact of Environmental Conditions: The Effect of Organizational commitment in Hong Kong and China. Journal of Environmental Psychology, 2, 353-368. http://dx.doi.org/10.1006/jevp.2001.0229

[51] Cass, M.H., Siu, O.L., Faragher, E.B. and Cooper, C.L. (2003) A Meta-Analysis of the Relationship between Job Satisfaction and Employee Health in Hong Kong. Stress and Health, 19, 79-95. http://dx.doi.org/10.1002/smi.959 